\title{
EVALUATION OF ANTIFUNGAL ACTIVITY OF Pittosporum undulatum L. ESSENTIAL OIL AGAINST Aspergillus flavus AND AFLATOXIN PRODUCTION
}

\author{
Avaliação da atividade antifúngica do óleo essencial de \\ Pittosporum undulatum L. em Aspergillus flavus e produção de aflatoxina
}

\author{
Rosane Tamara da Silva Medeiros ${ }^{1}$, Edlayne Gonçalez ${ }^{1}$, Roberto Carlos Felicio², Joana D’arc Felicio ${ }^{3}$
}

\begin{abstract}
The presence of mycotoxins as a result of fungal attack can occur before, after and during the harvest and storage operations on agricultural crops and food commodities. Considering the inhibitory property of essential plant oils on the mycelial development of fungi and the importance of Aspergillus flavus, the main producer of aflatoxins, this research was designed to evaluate the toxicity of essential oil from Pittosporum undulatum against $A$. flavus. The essential oils were obtained from $P$. undulatum leaves, collected in different months and analyzed by GC/MS. The oils were rich in hydrocarbon, monoterpenes and sesquiterpenes and it was observed a significant variation on the chemical composition of the essential oil of leaves at different months. Besides, the essential oils were tested against fungal growth and the results showed different spectrum of inhibition on A. flavus. However, the essential oils inhibited the aflatoxin $\mathrm{B}_{1}$ production.
\end{abstract}

Index terms: Aflatoxin $\mathrm{B}_{1}$, toxigenic fungal, volatiles, Pittosporaceae.

\section{RESUMO}

A presença de micotoxinas como resultado do ataque fúngico pode ocorrer antes, após e durante a colheita e também no armazenamento de grãos e alimentos. Considerando as propriedades inibitórias dos óleos essenciais de plantas no desenvolvimento do micélio dos fungos e a importâncias do Aspergillus flavus, principal produtor de aflatoxinas, relatou-se neste trabalho, a atividade tóxica do óleo essencial do Pittosporum undulatum em cultura de A. flavus. Os óleos essenciais de $P$. undulatum foram obtidos a partir de folhas coletadas em diferentes meses e analisado por CG/EM. Os óleos se mostraram ricos em hidrocarbonetos, monoterpenos e sesquiterpenos e foi observada uma significante variação na composição química destes óleos nos diferentes meses de coleta. Os óleos essenciais mostraram diferentes espectros de inibição do crescimento de $A$. flavus, porém todos foram capazes de inibir a produção de aflatoxina $\mathrm{B}_{1}$.

Termos para indexação: Aflatoxina $B_{1}$, fungos toxigêncos, voláteis, Pittosporaceae.

(Received in September 17, 2010 and approved in November 11, 2010)

\section{INTRODUCTION}

The increase of demand for safe and organic food, without chemical preservatives, provokes many researchers to investigate the antimicrobial effects of natural compounds. Numerous investigations have confirmed the antimicrobial action of essential oils in model food systems and in real food (Rasooli et al., 2008). Essential oils are a rich source of biologically active compounds and they are potential sources of novel antimicrobial compounds (Mitscher et al., 1987; Pereira et al., 2010). It was demonstrated that essential oils have been shown to possess antibacterial, antifungal, antiviral insecticidal and antioxidant properties (Burt, 2004; Kordali et al., 2005).

The essential oils mainly of the species of family Labiateae, Compositeae, Lamiaceae, Apiaceae, Asteraceae, Lauraceae and Umbellifereae were related as antifungal on toxigenic fungi (Mishra \& Dubey, 1994; Soliman \& Badeaa,
2002; Rasooli \& Owlia, 2005; Rasooli et al., 2006; RazzaghiAbyaneh et al., 2007; Bluma et al., 2008; Bluma \& Etcheverry, 2008; Nguefack et al., 2009; Viuda-Martos et al., 2009; Nogueira et al., 2010). Nogueria et al. (2010) related the activity of Ageratum conyzoides (Asteraceae) essential oil at $30 \mu \mathrm{g} / \mathrm{mL}$, to $0.10 \mu \mathrm{g} / \mathrm{mL}$ concentrations inhibited the growth of the Aspergillus flavus on average $55 \%$ and the aflatoxin production was completely inhibited all the concentrations.

The Aspergillus flavus can grow on a wide range of agricultural commodities, such as maize grains and is responsible to produce aflatoxins $\mathrm{B}_{1}$ and $\mathrm{B}_{2}$ (Bluma et al., 2008; Carvalho et al., 2010). Aflatoxin $B_{1}$ is the most carcinogenic, mutagenic and teratogenic substance found naturally in foods and feeds (International Agency for Research on Cancer - IARC, 1993). Therefore the control of A. flavus and of aflatoxin biosynthesis is extremely important for agriculture and public health.

${ }^{1}$ Biological Institute - Center for Research and Development of Animal Health - São Paulo, SP

${ }^{2}$ University State de Santa Cruz/UESC - Department of Chemistry/DCET - Bahia, BA

${ }^{3}$ Biological Institute - Center for Research and Development of Animal Health - Avenue Counselor Rodrigues Alves, 1252 - Vila Mariana 04014-002 - São Paulo, SP - felicio@biologico.sp.gov.br 
Pittosporum undulatum (Pittosporaceae) (named "pau-incenso" in Brazil) presents a characteristic smell from leaves and fruits. This species has been found as a wild plant in tropical forest from Africa, Asia and New Zealand and have been also planted as ornamental specie in other tropical regions of the world such as Brazilian cities (Lago et al., 2006). Medeiros et al. (2003) related the microbiology activity of the P. undulatum against Staphylococcus aureus and $S$. epidermis.

The present study report the principal components of the essentials oils obtained from leaves of $P$. undulatum collected in Ribeirão Pires at different months and their antifungal activity on Aspergillus flavus.

\section{MATERIAL AND METHODS}

\section{Plant materials}

Leaves of $P$. undulatum were collected in Ribeirão Pires city, São Paulo State, Brazil in November/2007 (Group I), December/2007 (Group II) and January/2008 (Group III). A voucher specimen ( $\mathrm{N}^{\circ}$. PMSP 9961) was deposited in the herbarium of the City Hall of São Paulo City.

\section{Oil extraction and analysis}

The fresh leaves were cut into small pieces and placed in a distillation Clevenger apparatus for 2 hours. The hydrolyte was extracted with hexane and evaporated at room temperature and the resulting oil was stored in dark glass bottles in a freezer until it was used by test in $A$. flavus and GC/MS analysis.

GC/MS analyses of the main components of essential oil and its fraction were done in a Shimadzu QP-5000 equipped with an OV-5 (30mx0.25mmx0.25 $\mu \mathrm{m}$, Ohio Valley Specialty Chemical, Inc) capillary column. Operating conditions were undertaken at oven temperature from $60^{\circ} \mathrm{C}$ to $240^{\circ} \mathrm{C}$ at $3^{\circ} \mathrm{C} / \mathrm{min}$, injector and detector temperatures of $240^{\circ} \mathrm{C}$ and $230^{\circ} \mathrm{C}$ respectively a $70 \mathrm{eV}$. Helium as a carrier gas at a constant flow of $1.7 \mathrm{~mL} / \mathrm{min}$, split 1/20. The oil components were identified using retention indices with those of authentic compounds or with literature data (Mclafferty \& Stauffer, 1989; Adams, 2001).

\section{Culture conditions}

The Aspergillus flavus strain producer of aflatoxin $\mathrm{B}_{1}$ was isolated from soil of rice plantation localized at Unidade Laboratorial de Referência de Microbiologia of Instituto de Tecnologia de Alimentos (ITAL)- Campinas SP. The fungi were plated onto potato dextrose agar (PDA) and incubated for 10 days at $25^{\circ} \mathrm{C}$. The spore suspension used as inoculum was prepared washing cultures with sterile $0.01 \%$ Tween 80 solution.

\section{Antifungal assay (disk diffusion assay)}

Filter paper disk (6mm diameter) containing $5.0 \mu \mathrm{L}$ of the crude essential oil of $P$. undulatum and the fractions were applied on the Sabouraud dextrose agar in Petri dishes previously inoculated with the fungal inoculum on the surface. The inoculated plates were incubated at $25^{\circ} \mathrm{C}$ for 5 days. At the end of the period, antifungal activity was evaluated by measuring the zone of inhibition (mm) against the test fungus (Yin et al., 1999). The fungicide Benlate $50 \mathrm{WP}$ was used with positive control. All treatments consisted of three replicates and repeated three times and the averages of the experimental results determined.

\section{Aspergillus flavus growth and aflatoxin production}

The semi-synthetic YES culture medium was used for aflatoxin production (Davis et al., 1966). Suspensions of A. flavus containing $1.3 \times 10^{5}$ spores $/ \mathrm{mL}$ were transferred to $50 \mathrm{~mL}$ of YES medium with different concentrations of essential oil $(0.1 \mu \mathrm{g} / \mathrm{mL}, 0.2 \mu \mathrm{g} / \mathrm{mL}, 0.3 \mu \mathrm{g} / \mathrm{mL})$. Four replicates were performed for each concentration, and the experiment was repeated three times. For production of aflatoxin $\mathrm{B}_{1}$, cultures were incubated at $25^{\circ} \mathrm{C}$ for 5 days. The cultures were filtered and submitted to drying at $50^{\circ} \mathrm{C}$ for 4 days. The weight of each mycelium was determined. To aflatoxin extraction, the filtrate was treated three times with $25 \mathrm{~mL}$ of chloroform. The extracts were combined, evaporated and the residue was dissolved in chloroform and made up to $1 \mathrm{~mL}$ in a volumetric flask. An aliquot $(40 \mu \mathrm{L})$ of each sample was spotted on silica gel-G thin layer plate (Merck, Germany) and then developed with chloroform: acetone 9:1 (v/v) as the solvent system. The concentration of aflatoxin $\mathrm{B}_{1}$ in each area was determined by photodensitometry (Shimadzu, CS 9000) comparing the area of the spots samples with aflatoxin $B_{1}$ standards (Sigma Aldrich, USA) (Gonçalez et al., 2001). The AFB quantification and detection limit were $0.08 \mathrm{ng}$ and 0.04 $\mathrm{ng}$, respectively.

\section{Statistical analysis}

Antifungal experiments were performed in triplicate and data analyzed are mean \pm SD subjected to one way ANOVA. Means are separated by Tukey's multiple range tests when ANOVA was signiûcant $(\mathrm{P}<0.05)$. 


\section{RESULTS AND DISCUSSION}

The essential oil extracted from $P$. undulatum leaves yielded $0.02 \%$. Chemical analysis by GC/MS of the essential oil from leaves of $P$. undulatum collected in Group I and Group III led to identiûcation of 11 and 14 main compounds, respectively and the Group II was constituted by 16 main compounds (Table 1).

Preliminary experiments were carried out in vitro using the disc diûusion methods to investigate antifungal activity of the essential oils from leaves of $P$. undulatum, using $5 \mu \mathrm{l}$ per disc. The Group II showed no inhibitory effect on A. flavus growth. Otherwise the Group I inhibited completely the fungal growth, and Group III demonstrated an inhibitory zone against $A$. flavus that was measure at $5.0 \mathrm{~mm}$ (average $\mathrm{n}=3$ ), comparing with the fungicide (Benlate) that was measure at $2.5 \mathrm{~mm}$.

According to the results obtained in the disc diffusion test, the Group III was submitted to the Yes test to evaluate the fungal growth and aflatoxin production. The results showed that both fungal growth and aflatoxin biosynthesis were suppressed by $P$. undulatum $\mathrm{L}$. The inhibitory effect on fungal growth of Group III increased according to the proportion of their concentrations. All concentrations of the essential oil reduced signiûcantly the mycelium dry weight $A$. flavus $(P<0.05)$ at concentrations of $0.1 \mu \mathrm{L} / \mathrm{mL}, 0.2 \mu \mathrm{L} / \mathrm{mL}, 0.3 \mu \mathrm{L} / \mathrm{mL}$ at $50.5 \%, 70.46 \%, 97.4 \%$, respectively. All concentrations tested in this study inhibited completely the aflatoxin production.

An important characteristic of essential oils and their components is their hydrophobicity, which enable them to partition the lipids of the bacterial and fungal cells membrane and mitochondria, disturbing the cells structures and rendering them more permeable (Sikkema et al., 1994; Nogueira et al., 2010).

Aspergillus flavus is a spoiling mould and aûatoxins producer that reduces the nutritive values of foods becoming them unût for human consumption. Some essential oils of ethno medicinally important higher plant species have been tested for their antifungal activity (Kumar et al., 2010). The inhibition of A. flavus growth by essential oils has already been reported (Dikbas et al., 2008; Kumar et al., 2008, 2010; Viuda-Martos et al., 2008; Nogueira et al., 2010). However there are no reports that describe the effect of $P$. undulatum essential oil as an inhibition of $A$. flavus growth and aflatoxin synthesis.

The results of the present study revealed that essential oil of leaves of $P$. undulatum demonstrated an inhibitory activity against $A$. flavus fungi and aflatoxin production in lower concentrations $0.3 \mu \mathrm{L} / \mathrm{mL}$. The total inhibition of aûatoxin production was observed using the essential oils at $0.1 \mu \mathrm{L} / \mathrm{mL}, 0.2 \mu \mathrm{L} / \mathrm{mL}, 0.3 \mu \mathrm{L} / \mathrm{mL}$. A similar result was reported by Kumar et al. (2010) that observed a complete inhibition of aûatoxin $\mathrm{B}_{1}$ production by Ocimum sanctum essential oil and eugenol at 0.2 and $0.1 \mu \mathrm{L} / \mathrm{mL}$.

The inherent activity of essential oil can be expected to relate to the chemical conûguration of the components, the proportion in which they are present and the interactions between them (Delaquis et al., 2002). Comparing the two groups with antifungal activity (Group I and III) it was observed that the chemical constitution are similar, just varying in the amount of the constituents. The chemical profile of Group II was very different. The composition of groups I and II showed more hidrocarbon compounds that group II. The 4-terpeniol and spatulenol were main compounds of the Group II and 2-heptanone and 3-methyl-4-heptanone and n-heptanol (Table 1) were the main constituents of the essential oil of Group I and III. Although the collection has been performed in the same plant and these data have been attributed to the influence of abiotic factors that occurred in different months.

The literature data report the predominance of the same class (sesquiterpenes) according to the chemical profile of essential oils obtained in this present study but no report cited substances with internal fragmentation of masses. This difference in chemical composition justifies the obtained results on the antifungal activity of plant essential oils (Medeiros et al., 2003; Lee et al., 2004). Lago et al. (2006) identified the monoterpene: $\beta$-pinene, $\beta$-myrcene, limonene, $\delta$-elemene and sesquiterpenes: $\alpha$-copaene, $\beta$-elemene, $\beta$-caryophyllene, aromadendrene, bicyclogermacrene, $\delta$-cadinene, being limonene the main constituent of essential oil $P$. undulatum, on the other hand, Medeiros et al. (2003) related that $P$. undulatum oil essential contain monoterpenes, sesquiterpenes, diterpenes and alkanes, such as: calamenene (41.4\%), farnesol (10.9\%), spathulenol (5.6\%) and $\beta$-selinene (5.2\%) and the diterpene $(8 \beta, 13 \beta)$-kaur-16-ene (10.7\%).

The same author described the antimicrobial activities tested against Staphylococcus aureus, $S$. epidermis and Pseudomonas aeruginosa, and those oils with the highest activities against $S$. aureus and $S$. epidermis were obtained from $H$. gardnerianum; none had activity against $P$. aeruginosa (Medeiros et al., 2003).

The composition of essential oil plants varies significantly in different genera, species and environmental conditions which the plant is subjected. The variation in fungical toxicity of tested essential oil against toxigenic strain of A. flavus may be due to considerable diversity in essential oil constituents (Kumar et al., 2008). 
Table 1 - Identified compounds, retention time and percentage composition from essential oil of the leaves of Pittosporum undulatum collected in November/2007 (Group I), December/2007 (Group II) and January/2008.

\begin{tabular}{|c|c|c|c|c|}
\hline Compound & $\begin{array}{l}\text { Retention } \\
\text { time (min) }\end{array}$ & $\begin{array}{c}\text { Group I } \\
(\%)\end{array}$ & $\begin{array}{c}\text { Group II } \\
(\%)\end{array}$ & $\begin{array}{l}\text { Group III } \\
(\%)\end{array}$ \\
\hline 2-heptanone & 4.95 & 30.96 & 2.08 & 25.64 \\
\hline 3-methyl-4-heptanone & 5.36 & 19.78 & 2.55 & 17.47 \\
\hline Sabinene & 5.74 & 1.15 & nd & 0.93 \\
\hline B-pinene & 5.85 & 1.03 & nd & 0.82 \\
\hline$\alpha$-mircene & 5.91 & 7.34 & nd & 7.42 \\
\hline n-heptanol & 6.52 & 18.75 & 1.95 & 19.92 \\
\hline$\alpha$-decene & 7.23 & 1.54 & nd & 1.45 \\
\hline limonene & 7.35 & 1.23 & nd & 1.32 \\
\hline Trans-3-hexenil acetate & 7.67 & 1.17 & nd & 0.57 \\
\hline Cis-3-hexenil acetate & 7.82 & 0.62 & nd & 5.44 \\
\hline 4-terpineol & 14.10 & nd & 25.58 & 5.44 \\
\hline$\alpha$-terpineol & 14.62 & nd & 2.53 & 1.40 \\
\hline n-dodecane & 15.25 & 0.34 & 1.34 & 1.36 \\
\hline n-tridecane & 19.47 & nd & 3.39 & 0.52 \\
\hline n-tetradecane & 23.65 & nd & 7.88 & nd \\
\hline n-pentadecane & 27.69 & nd & 6.04 & nd \\
\hline$\gamma$-cadinene & 28.08 & nd & 2.63 & nd \\
\hline cubenene & 28.79 & nd & 4.13 & nd \\
\hline spatulenol & 30.46 & nd & 13.52 & nd \\
\hline cariophyllene oxid & 30.72 & nd & 3.02 & nd \\
\hline n-hexadecane & 31.54 & nd & 2.19 & nd \\
\hline n-heptadecane & 35.21 & nd & 1.46 & nd \\
\hline EE-farnesol & 35.80 & nd & 4.00 & nd \\
\hline
\end{tabular}

\section{CONCLUSION}

The results of this study showed the efficiency of the essential oil from leaves of P. undulatum on growth inhibition and aflatoxin B1 production by A. flavus. However, his efficacy as fungicide is depends of environmental conditions and the period of year.

\section{ACKNOWLEDGMENT}

The authors are grateful to the Conselho Nacional de Desenvolvimento Científico e Tecnológico (CNPq) by the exchange of scientific initiation of R.T. Medeiros.

\section{REFERENCES}

ADAMS, R.P. Identification of essential oil components by gas chromatography/mass spectroscopy. Illinois: Allured, 2001. 468p.
BLUMA, R.V.; AMAIDEN, M.R.; DAGHERO, J.; ETCHEVERRY, M. Control of Aspergillus section Flavi growth and aflatoxin accumulation by plant essential oils. Journal Applied Microbiology, Oxford, v.105, p.203214, 2008.

BLUMA, R.V.; ETCHEVERRY, M.G. Application of essential oils in maize grain: impact on Aspergillus section Flavi growth parameters and aflatoxin accumulation. Food Microbiology, v.25, p.324-334, 2008.

BURT, S. Essential oils: their antibacterial properties and potential applications in foods: a review. International Journal of Food Microbiology, Grugliasco, v.94, p.223253, 2004. 
CARVALHO, R.A. de; BATISTA, L.R.; PRADO, G.; OLIVEIRA, B.R. de; SILVA, D.M. da. Incidência de fungos toxigênicos e aflotoxinas em arroz. Ciência e Agrotecnologia, Lavras, v.34, n.4, p.946-952, jul./ago., 2010.

DAVIS, N.D.; DIENER, U.L.; ELDRIDGE, D.W. Production of aflatoxin B1 and G1 by Aspergillus flavus in semisynthetic medium. Applied Microbiology, Bethesda, v.14, p.378-380, 1966.

DELAQUIS, P.J.; STANICH, K.; GIRARD, B.; MAZZA, G. Antimicrobial activity of individual and mixed fractions of dill, cilantro, coriander and eucalyptus essential oils.

International Journal of Food Microbiology, Grugliasco, v.74 p.101-109, 2002.

DIKBAS, N.; KOTAN, R.; DADASOGLU, F.; SAHIN, F. Control of Aspergillus flavus with essential oil and methanol extract of Satureja hortensis. International Journal of Food Microbiology, Grugliasco, v.124, p.179$182,2008$.

GONÇALEZ, E.; FELICIO, J.D.; PINTO, M.M. Biflavonoids inhibit the production of aflatoxin by Aspergillus flavus. Brazilian Journal of Medical and Biological Research, Ribeirão Preto, v.34, p.1453-1456, 2001.

\section{INTERNATIONALAGENCY FOR RESEARCH ON}

CANCER. Monographs on the evaluation of carcinogenic risks to humans. Lyon, 1993. 263p.

KORDALI, S.; KOTAN, R.; MAVI, A.; CAKIR, A.; ALA, A.; YILDIRIM, A. Determination of the chemical composition and antioxidant activity of the essential oil of Artemisia dracunculus and of the antifungal and antibacterial activities of Turkish Artemisia absinthium, A. dracunculus, Artemisia santonicum, and Artemisia spicigera essential oils. Journal Agriculture and Food Chemistry, Washington, v.53, p.9452-9458, 2005.

KUMAR, A.; SHUKLA, R.; SINGH, P.; DUBEY, N.K. Chemical composition, antifungal and antiaûatoxigenic activities of Ocimum sanctum L. essential oil and its safety assessment as plant based antimicrobial. Food Chemistry and Toxicology, Richmond, v.48, p.539-543, 2010 .
KUMAR, A.; SHUKLA, R.; SINGH, P.; PRASAD, C.S.; DUBEY, N.K. Assessment of Thymus vulgaris L. essential oil as a safe botanical preservative against postharvest fungal infestation of food commodities. Innovative Food Science and Emerging Technologies, v.9, p.575-580, 2008.

LAGO, J.H.G.; FÁVERO, O.A.; ROMOFF, P.

Microclimatic factors and phenology influences in the chemical composition of the essential oils from Pittosporum undulatum vent. Leaves. Journal of Brazilian Chemical Society, São Paulo, v.17, p.13341338, 2006.

LEE, S.E.; PARK, B.S.; BAYMAN, P.; BAKER, J.L.; CHOI, W.S.; CAMPBELL, B.C. Suppression of ochratoxin biosynthesis by naturally occurring alkaloids. Food Additives and Contaminants, v.24, p.391-397, 2007.

MCLAFFERTY, F.W.; STAUFFER, D. The Wiley / NBS registry of mass spectral. New York: Wiley, 1989.

MEDEIROS, J.R.; CAMPOS, L.B.; MENDONÇA, S.C.; DAVINC, L.B.; LEWISC, N. Composition and antimicrobial activity of the essential oils from invasive species of the Azores, Hedychium gardnerianum and Pittosporum undulatum. Phytochemistry, London, v.64 p.561-565, 2003.

MISHRA, A.K.; DUBEY, N.K. Evaluation of some essential oils for their toxicity against fungi causing deterioration of stored food commodities. Applied and Environmental Microbiology, Washington, v.60, p.11011105, 1994.

MITSCHER, L.A.; DRAKE, S.; GOLLAPUDI, S.R.; OKWUTE, S.K. A modern look at folkloric use of antiinfective agents. Journal of Natural Products, v.50, p.1025-1040, 1987.

NGUEFACK, J.; DONGMO, J.B.L.; DAKOLE, C.D.; LETH, V.; VISMER, H.F.; TORP, J.; GUEMDJOM, E.F.N.; MBEFFO, M.; TAMGUE, O.; FOTIO, D.; ZOLLO, P.H.A.; NKENGFACK, A.E. Food preservative potential of essential oils and fractions from Cymbopogon citratus, Ocimum gratissimum and Thymus vulgaris against mycotoxigenic fungi. International Journal of Food Microbiology, Grugliasco, v.131, p.151-156, 2009. 
NOGUEIRA, J.H.C.; GONÇALEZ, E.; GALLETI, S.R.; FACANALI, R.; MARQUES, M.O.M.; FELICIO, J.D. Ageratum conyzoides essential oil as aûatoxin suppressor of Aspergillus ûavus. International Journal of Food Microbiology, Grugliasco, v.137, p.55-60, 2010.

\section{PEREIRA, E.L.; BARROS, C.S.; ROSSETTO, C.A.V.} Contaminação de sementes de amendoim, inoculadas por Aspergillus secção Flavi, influenciada pelo genótipo, pela área de cultivo e pelos isolados. Ciência e Agrotecnologia, Lavras, v.34, n.4, p.853-859, jul./ago., 2010.

RASOOLI, I.; FAKOOR, M.H.; YADEGARINIA, D.; GACHKAR, L.; ALLAMEH, A.; REZAEI, M.B.

Antimycotoxigenic characteristics of Rosmarinus ofûcinalis and Trachyspermum copticum L. essential oils. International Journal of Food Microbiology, Grugliasco, v.122, p.135-139, 2008.

RASOOLI, I.; OWLIA, P. Chemoprevention by thyme oils of Aspergillus parasiticus growth and aflatoxin production. Phytochemistry, London, v.66, p.2851-2856, 2005.

RASOOLI, I.; REZAEI, M.B.; ALLAMEH, A. Growth inhibition and morphological alterations of Aspergillus niger by essential oils from Thymus eriocalyx and Thymus X-porlock. Food Control, Guildford, v.17, p.359364, 2006.
RAZZAGHI-ABYANEH, M.; SHAMS-GHAHFAROKHI, M.; YOSHINARI, T.; REZAEE, M.; JAIMAND, K.; NAGASAWA, H.; SAKUDA, S.; TZORTZAKIS, N.G. ECONOMAKIS, C.D. Antifungal activity of lemongrass (Cympopogon citratus L.) essential oil against key postharvest pathogens. Innovative Food Science and Emerging Technologies, v.8, p.253-258, 2007.

SIKKEMA, J.; BONT, J.A.M.; POOLMAN, B. Interactions of cyclic hydrocarbons with biological membranes. Journal of Biological Chemistry, Richmond, v.269, p.8022-8028, 1994.

SOLIMAN, K.M.; BADEAA, R.I. Effect of oil extracted from some medicinal plants on different mycotoxigenic fungi. Food Chemistry and Toxicology, Richmond, v.40, p.1669-1675, 2002.

VIUDA-MARTOS, M.; RUIZ-NAVAJAS, Y.; FERNÁNDEZ-LÓPEZ, J.; PEREZ-ÁLVAREZ, J. Antibacterial activity of lemon (Citrus lemon 1.), mandarin (Citrus reticulata 1.), grapefruit (Citrus paradisi 1.) and orange (Citrus sinensis 1.) essential oils. Journal of Food Safety, v.28, p.567-576, 2008.

YIN, M.C.; TSAO, S.M. Inhibitory effect of seven Allium plants upon three Aspergillus species. International Journal of Food Microbiology, Grugliasco, v.49, p.49-56, 1999. 